\title{
Pompa Air Harapan: Upaya Penanggulangan Kekeringan dan Pengembangan Usaha Mandiri Masyarakat Desa Kwadungan Lor, Kabupaten Ngawi
}

\author{
Churnia Sari, Bayu Fandidharma, Yudha Ragil \\ Fakultas Teknik, Universitas PGRI Madiun \\ s.churnia@unipma.ac.id
}

\begin{abstract}
Abstrak
Ngawi adalah salah satu kota di Jawa Timur yang terletak di dataran rendah dan merupakan satu dari lima kota pemasok padi terbanyak. Sehingga nilai lahan di Kabupaten Ngawi menjadi sangat penting, sebagai penunjang ekonomi masyarakat. Namun berdasarkan observasi dan pemberitaan pada media elektronik, beberapa lahan di Ngawi tidak dapat diolah secara maksimal ketika musim kemarau, dan belum ada solusi yang ditawarkan terkait masalah tersebut. Program pendistribusian air dari Pemerintah Kabupaten (Pemkab) Ngawi sudah dijalankan, tetapi belum merata di seluruh wilayah terutama desa-desa yang secara geografis cukup sulit untuk dijangkau. Alasan ini mendasari Pengabdian Masyarakat dilaksanakan di Kabupaten Ngawi. Dari hasil observasi, dipilih desa Kwadungan Lor sebagai lokasi Pengabdian Masyarakat. Dengan adanya Program Pompa Air Harapan, masyarakat Kwadungan Lor menjadi lebih semangat dalam mengelola lahannya sekaligus bisa memperoleh keuntungan dari hasil bercocok tanam.
\end{abstract}

Kata Kunci: Dataran Rendah, Kekeringan, Pompa Air

\section{Abstract}

Ngawi is one of the towns in East Java located in the lowlands and Ngawi is also one of the five most rice-supplying towns. So the land in Ngawi is very valuable as economic support. However, based on observations and reports on electronic media, some land in Ngawi cannot be optimally cultivated during the dry season, and there is no solution offered regarding this problem. The water distribution program from the Government (Ngawi) has been implemented, but it has not been evenly distributed in all areas of villages that are difficult to reach. That is the reason for dedication there. From observation, Kwadungan Lor was chosen as the location to get support and service "Pompa Air Harapan". "Pompa Air Harapan" Program that has been applied make Kwadungan Lor citizen more enthusiastic to manage their land during the dry season and can get benefit from it.

Keywords: The Lowland, Drought, Water Pump

\section{PENDAHULUAN}

Kwadungan Lor adalah sebuah desa di Kecamatan Padas, Kabupaten Ngawi, Propinsi Jawa Timur. Desa ini berjarak \pm 11 km dari Pusat Kabupaten Ngawi, namun untuk masuk kedalam masih membutuhkan $\pm 11 \mathrm{~km}$ lagi untuk tepat ada di Kwadungan Lor, dan hanya bisa dilalui oleh kendaraan roda dua. Untuk menuju kesana diperlukan waktu \pm 1 jam. Medan jalan yang berbatu menjadi hambatan utama desa ini tidak dapat dijangkau kendaraan roda 4. Desa Kwadungan Lor mempunyai tekstur tanah yang 
tergolong kering, ${ }^{1}$ karena faktor geologi berupa lapisan batu di Desa ini cukup minim, sehingga tidak banyak air tanah yang dapat meresap. Faktor geologi ini cukup membuat kondisi sungai dan sumber air tidak bisa diandalkan oleh Masyarakat Desa Kwadungan Lor. Meskipun memiliki lahan yang luas dan kosong masyarakat tidak bisa memaksimalkan potensi lahanya. Hampir semua warga bekerja sebagai petani, baik sebagai pemilik maupun penggarap lahan. ${ }^{2}$ Namun, para petani ini tidak bisa lebih berkembang karena biaya yang digunakan untuk bercocok tanam sudah sangat banyak. Mereka harus membeli air dari orang - orang yang memasang sumur bor di desa tersebut dengan harga yang mahal karena minimnya sumber air dan sumur bor yang dimiliki oleh warga setempat. Berdasarkan hasil wawancara dengan warga setempat, jika pada umumnya di desa lain petani yang tidak memiliki sumur bor dapat membeli air dengan harga Rp. 40.000,-/ jamnya, di Kwadungan Lor ketika musim kemarau petani harus membayar Rp 60.000,-/ jamnya. Harga tersebut sangat mahal bagi petani di Kwadungan Lor, karena selain harus membeli air, para petani masih harus menanggung beban biaya pemupukan, tenaga tanam dan tenaga panen. Rata-rata petani harus mengelurakan biaya \pm Rp. 2.125.000,- untuk satu kali panen. Sedangkan hasil penjualan gabah rata-rata yang bida didapatkan petani adalah Rp. 3.250.000,-. Sehingga para petani tidak mendapatkan banyak keuntungan selama 2 kali masa panen pada musim kemarau, bahkan sebagian dari mereka memilih untuk tidak memanfatkan lahannya ketika musim kemarau karena tingginya biaya pengairan dan pemupukan. Sedangkan untuk bisa membuat sumur bor sendiri juga dibutuhkan biaya yang cukup besar ${ }^{3}$. Berdasarkan seluruh permasalahan tersebut, dilakukan Program Pompa Air Harapan di Desa Kwadunga Lor.

Harapannya dengan program "Pompa Air Harapan" untuk Masyarakat Desa Kwadungan Lor, Padas, Ngawi, dapat meningkatkan taraf hidup dan dapat membuat para petani lebih bergairan dalam memanfaatkan lahannya untuk menunjang kehidupan mereka. Jika air bisa diakses dengan mudah dan murah, warga akan dapat meminimalkan biaya pengairan dan dapat mengalokasikan anggaran untuk memenuhi kebutuhan yang lainya. Selain itu, para petani juga bisa mengembangkan usaha lain selain bercocok tanam, atau warga masyarakat dapat menggunakan air untuk membuka lahan kering yang tidak digunakan sebagai tempat bercocok tanam selain padi. Diharapkan desa ini bisa mengembangkan usaha-usaha lainya yang lebih kreatif

1 Putri A. Melato, dkk. "Sistem Aliran dan Potensi Air Tanah di Sebagian Desa Sembangun Ditinjau dari Aspek Kualitas dan Kuantitas" (2018) 32:2 Majalah Geografi Indonesia 155.

2 Musyarofah, dkk. "Prefensi Petani dalam Penjualan Gabah Pasca Panen di Desa Sumur Mati, Kecamatan Sumber Asih, Kabupaten Probolinggo” (2017) ll:1 Jurnal Pendidikan Ekonomi 81.

3 Sunarsih Ernawati S, "Air Bersih untuk Masyarakat Miskin dengan Sumur Bor" (2012) 3:2 Journal of Rural and Development 113.

4 Wibowo Agus T., M. Zen Kadir, Iskandar Zulkarnanen, "Peranan Sumur Bordalam Mengefektifkan Penyediaan Air Bersih Masyarakat Kampung Sukamanjur Kelurahan Bumi Kedamaian" (2015) 1 Artikel Ilmiah Teknik Pertanian Lampung 19. 
dan mendatangkan banyak keuntungan dari hasil usahanya ${ }^{4}$. Untuk dapat melaksanakan program ini dengan baik maka beberapa pihak yang terlibat aktif adalah Kepala Desa, Ketua Takmir Masjid Al Hijrah, serta wakil dari Lembaga Masyarakat (Perwakilan dari salah satu petani yang memiliki lahan terbanyak). Beberapa diskusi dilakukan secara bertahap, sampai terdapat kesepakatan terkait dengan pemasangan Pompa dan kebijakan penggunaan airnya oleh masyarakat desa.

\section{TINJAUAN MASALAH}

Desa Kwadungan Lor memiliki struktur tanah kapur yang cukup sulit untuk dijadikan sebagai media tanam. Selain karena sifatnya secara geografis tidak subur, kondisi semakin sulit ketika musim kemarau datang, Ketika musim hujan masyarakat masih bisa bercocok tanam pada lahan yang mudah dialirkan air irigasi. Padi, tebu, jagung, dan sayur-sayuran masih bisa tumbuh dengan baik, sehingga ketika dijual ke tengkulak untuk semua hasil panen yang didapatkan, masyarakat masih mendapatkan untung yang bisa digunakan untuk modal tanam berikutnya. Namun ketika musim kemarau datang para petani tidak dapat lagi mengandalkan keuntungan dari hasil panen padi, kerana dalam satu kali masa panen, para petani pada umumnya hanya mendapatkan \pm Rp. 1.700.000,-. Hasil dari 1 kali masa panen sulit untuk digunakan kembali sebagai modal tanam, karena sudah habis untuk memenuhi kebutuhan hidup sehari-hari. Sehingga para petani hanya akan mengandalkan hasil tanam, dari tumbuhan lain, seperti kacang tanah, kedele, atau hanya ketela dan pisang.

Situasi semakin sulit karena tidak banyak air yang bisa digunakan untuk pengairan atau bercocok tanam. Selain permasalahan dengan keterbatasan air, masyarakat tidak bisa dengan mudah menjual hasil cocok tanam keluar karena sulitnya akses menuju luar desa. Sehingga masyarakat hanya bergantung pada tengkulak yang datang ke desa dan sebagian dikonsumsi untuk dimakan sendiri. Kehidupan seperti itu terus berulang dari tahun ketahun tanpa ada kemajuan yang signifikan, sehingga penghasilan masyarakat pada desa ini tak kunjung membaik. Penghasilan yang rendah membuat warga tidak bisa mendapatkan pekerjaan yang mapan serta pendidikan yang tinggi. Seperti misalnya, dari seluruh kepala keluarga yang ada di Desa Kwadungan Lor, hanya ada 1 kepala keluarga yang dapat menyekolahkan anaknya sampai lulus Dl, dan sekarang bisa bekerja di Surabaya.

Tidak ada kemajuan dalam kehidupan masyarakat Desa Kwadungan Lor, karena tidak pernah ada solusi yang ditawarkan, lantaran perangkat Desa juga kurang mendapatkan banyak informasi, terlebih warga masyarakat juga sudah terbiasa dengan kondisi seperti itu, sehingga perangkat Desa tidak pernah menawarkan bantuan atau musyawarah untuk mengatasi kekeringan yang selalu muncul setiap tahunya. Jika kekeringan terjadi, kehidupan masyarakat menjadi semakin sulit. Berdasarkan wawancara dengan warga setempat, warga hanya akan sibuk membeli air untuk kebutuhan sehari-hari karena sumur-sumur warga juga mengering. 
"disini buat menuhi kebutuhan air aja susah mbak harus beli lewat truk-truk biasnya seminggu sekali lewat bawa galon-galon mbak, pada kering sumurnya kalo kemarau, jadi saya nggak nanem padi dulu soalnya nggak ada modalnya". (CakJo 55 th)

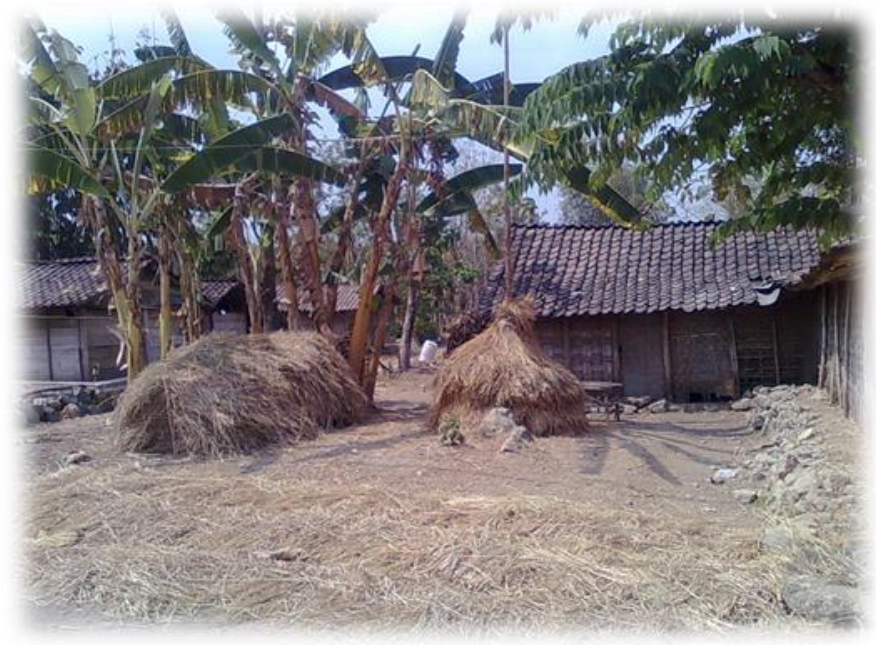

\section{Gambar 1.1 Keadaan Desa}

"alhamdulillah kalo sumur saya nggak kering banget mas, tapi ya gitu kita tetep nggak bisa tanam padi, nggak untung soalnya, jadi yo tanem kacang aja sama kedele, minimal masih ada masukan dan nggak rugi" (Umi 28 th)

Oleh karena itu, program ini diharapkan mampu mewadahi aspirasi dan menjalin kesepakatan untuk pembuatan Sumber Air Umum. Tanah yang digunakan untuk digali sumber airnya, kekurangan dana untuk pembelian pompa yang digunakan telah dimusyawarahkan dan diputuskan untuk dilakukan iuran dari warga serta pengajuan Proposal dana Hibah Bantuan Desa sehingga dapat menjadi program berkesinambungan dengan tujuan akhir desa Kwadungan Lor dapat menjadi Desa Binaan. Program ini, sebagai langkah awal untuk memulai semua proses, dimulai dengan mewadahi sebuah musyawarah untuk mufakat serta memberikan bantuan untuk mendeteksi sumber air dan melakukan pengeboran.

\section{PELAKSANAAN}

Pada kegiatan ini, disepakati bahwa kekurangan dana untuk pembelian diesel (pompa air) diusahakan secara bersama-sama. Mulanya, musyawarah akan dilakukan dengan para pejabat desa, setelah ide dapat disampikan dan dapat diterima, maka akan disosialisasikan lewat Anggota Permusyawarahan Desa untuk disebarakan kepada masyarakat Desa Kwadungan Lor. Langkah selanjutnya adalah melakukan tinjau lokasi yang sudah ditentukan oleh Kepala Desa untuk dideteksi terkait sumber mata air dan dilakukan pengeboran pada lokasi yang sudah ditentukan. Lokasi pembuatan sumur diputuskan dengan persetujuan antara pihak pemberi bantuan dengan yang dibantu. Pengeboran dilakukan oleh pawang air dan timnya. Kegiatan pembuatan sumur bor ini akan dilaksanakan pada bulan ke-lima, saat kegiatan pengabdian ini berlangsung dan 
akan dilaksanakan di desa Kwadungan Lor, Kecamatan Padas, Kabupaten Ngawi. Kegiatan pengabdian berupa pembuatan sumur bor ini akan dilaksanakan dalam beberapa tahap, meliputi:

\section{A. Tahap Persiapan}

Tahap persiapan yang dilakukan untuk melaksanakan program ini meliputi, pembuatan proposal dan menyelesaikan administrasi perijinan pada instansi yang akan dilibatkan pada pelaksanaan kegiatan. Tahap ini membutuhkan waktu 1 minggu. Dalam penyusunan proposal, sudah dilibatkan satu warga desa Kwadungan Lor dan mahasiswa juga melakukan tinjau langsung ke lokasi. Setelah diperoleh ijin dari kepala desa, maka dilakukan pengkajian lebih dalam pada kondisi tanah di desa Kwadungan Lor.

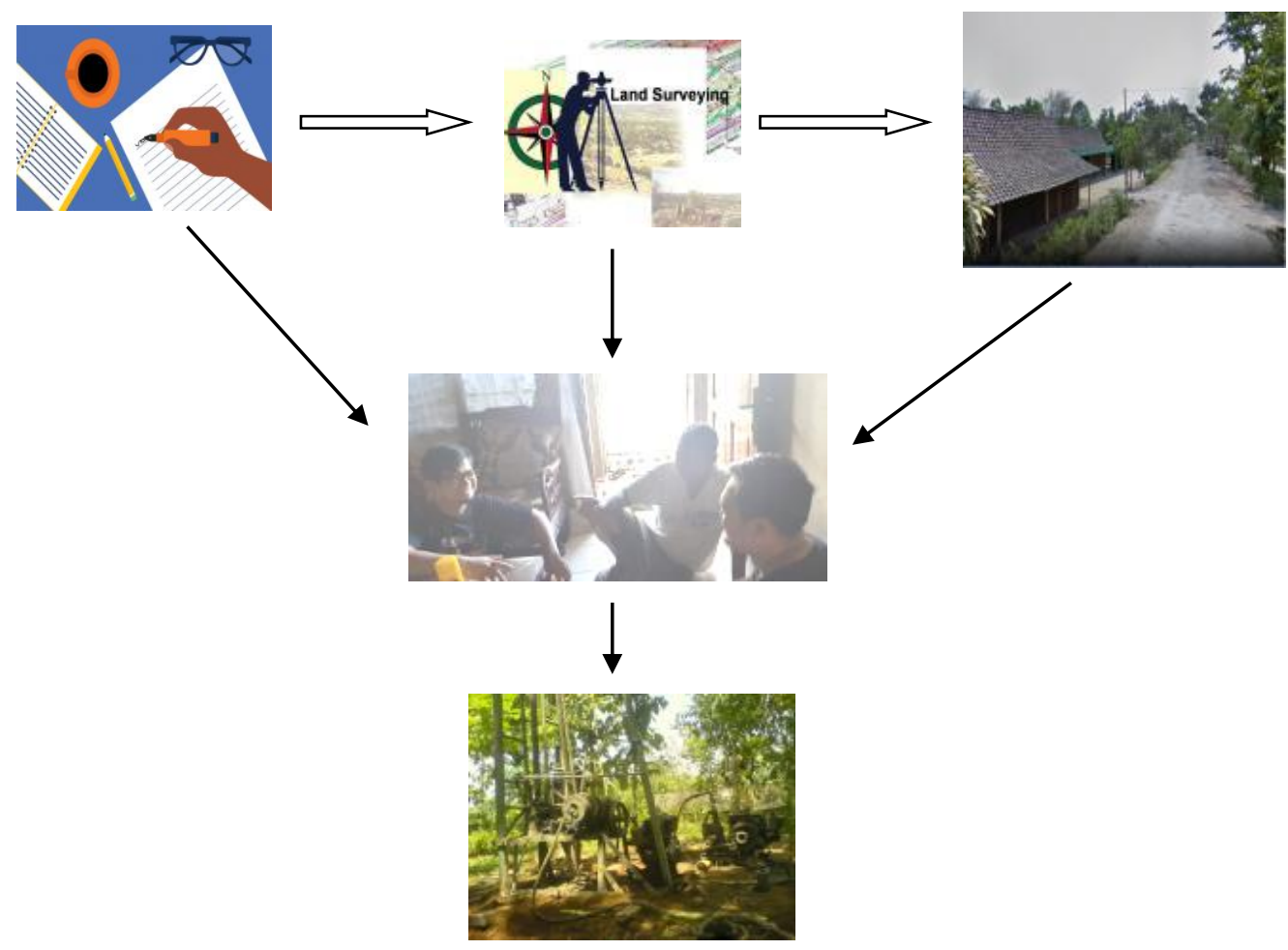

Gambar 2.1 Tahap Persiapan

Seminggu kemudian dilakukan kunjungan yang kedua yang dimaksud untuk melakukanmusyawarahbersama kepala desa dan wakil warga yang terdiri dari Ketua Takmir Masjid Al- Hijrah, pemilik lahan yang akan digali dan diteliti kadar air lahannya, serta satu wakil warga yang mewakili para petani. Setelah diperoleh kesepakatan untuk pelaksanan kegiatan maka didatangkan pawang air untuk mendeteksi tanah yang bisa dipasang sumur bor. Dengan metode sederhana menggunakan garam dan tempurung kelapa yang dilakukan oleh pawang air, didapatkan tiga titik tanah yang berpotensi mengeluarkan air yang cukup besar. Tahap akhir persiapan adalah penggalangan dana tambahan untuk biaya pembelian pompa air. 


\section{B. Tahap Pelaksanaan}

Tahap pelaksanaan program meliputi musyawarah dengan warga sekitar, sosialisasi, dan melakukan koordinasi secara keselurahan terkait pembuatan sumur bor. Tahap ini sepenuhnya dilakukan oleh pekerja yang telah disewa. Posisi pengeboran juga telah ditentukan oleh pawang air dan sudah disepakati dengan warga sebelumnya. Untuk pemasangan pompa dilakukan pada periode berikutnya menunggu ketersedian pompa dari warga.

\section{Tahap Akhir}

Tahap akhir terdiri dari sosialisasi kepada warga tentang himbauan untuk efektif dalam kelanjutan program ini dan dapat memanfaatkan sebaik mungkin air yang telah tersedia untuk kesejahteraan seluruh warga desa.

\section{HASIL DAN PEMBAHASAN}

Meskipun diskusi berjalan cukup pelik karena adanya beberapa warga yang masih ragu akan adanya program ini dan khawatir akan timbul masalah kedepannya tentang pemakaian air, kepala desa mampu menengahi dengan baik. Dihasilkan mufakat bahwa sumber air ini juga digunakan sebagai penyalur air utama ke masjid, sehingga warga yang menggunakanya harus mengalirkannya dari masjid, dan akan di jaga serta diawasi oleh takmir masjid. Tim juga menjelaskan secara perlahan manfaat dari program ini kedepannya agar warga bisa memanfaatkan air untuk usaha lain, serta dapat menambah jumlah pompa air jika warga telah berhasil merintis sebuah usaha yang cukup menguntungkan. Penambahan pompa air diperlukan agar distribusi air dapat menjangkau warga desa yang rumahnya jauh dari letak sumur Bor.

Berdasarkan diskusi yang dilakukan, dihasilkan sebuah rencana ke depan yang bisa dikembangkan lagi yaitu kolam ikan terpal untuk pemeliharaan ikan lele disekitar sumur Bor, sekaligus memanfaatkan lahan yang kosong. Rencana ini disambut baik oleh kepala desa tapi tidak untuk warga karena mereka merasa keberatan untuk mengeluarkan baiaya kembali. Akhirnya disepakati bahwa desa ini akan menjadi Desa Binaan yang program selanjutnya akan dibuatkan kolam ikan terpal sebagai usaha bersama desa dengan bantuan dari luar. Berikut adalah beberapa dokumentasi selama proses pembuatan dan ketika sumur bor telah mengeluarkan air tanah pada Gambar 1.3 dan Gambar 1.4. 


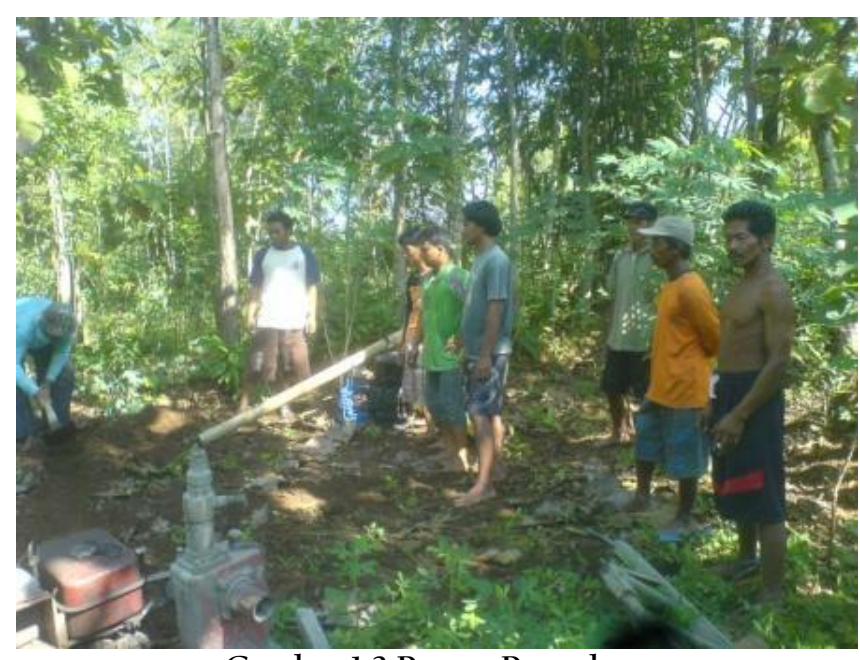

Gambar 1.3 Proses Pengeboran

Proses pengeboran dan pemasangan pompa berlangsung selama 3 hari, karena lamanya proses pemilihan lokasi tanah yang akan di bor, dan pembelian Pompa Air oleh warga. Setelah pemilihan lokasi tanah, juga terdapat sedikit masalah karena tanah yang akan dijadikan sumber air dan digali, tidak diijinkan oleh pemiliknya untuk digunakan sehingga pemilihan lokasi berganti sampai tiga kali dan ahirnya ada seorang warga yang mengijinkan tanahnya digunakan dengan beberapa kesepakatan. Namun masih ada beberapa masalah terkait penggunaan airnya, oleh karena itu musyawarah lanjutan masih perlu diadakan. Masyarakat Desa Kwadunga Lor termasuk masyarakat yang cukup kooperatif jika ada yang memulai inisiasi, sehingga pada musyawarah selanjutnya diperoleh keepakatan yang jelas terkait aturan untuk penggunaan air. Kedepanya, diharapkan setelah terjadi kesepakatan penggunaan air, program lanjutan kolam ikan terpal juga akan berhasil dilaksanakan.

Pengabdian masyarakat ini selesai dalam waktu satu bulan. Beberapa hal yang telah disepakati dan dihasilkan antara lain:

a. Terlaksananya sebuah diskusi antara warga dan Petinggi Desa untuk mengatasi permasalahan kekeringan yang sering melanda Desa Kwadungan Lor

b. Warga sepakat untuk bersama-sama menutup kekurangan uang untuk pembelian Pompa Air dengan iuran sukarela dan uang kas desa.

c. Tanah yang digunakan untuk penggalian dan penempatan sumur bor telah diwaqafkan oleh pemilik untuk dipakai secara bersama dengan peraturan yang telah disepakati.

d. Telah disepakati pula, bahwa air yang keluar dari pompa akan disalurkan ke penampung air di Masjid Al Hijrah, dan dibuatkan keran-keran untuk berwudhu sekaligus untuk memudahkan warga jika hendak mengambil air untuk keperluan sehari hari. Untuk keperluan irigasi warga bisa langsung mengambil air dari tempat dimana sumur bor dibuat. 


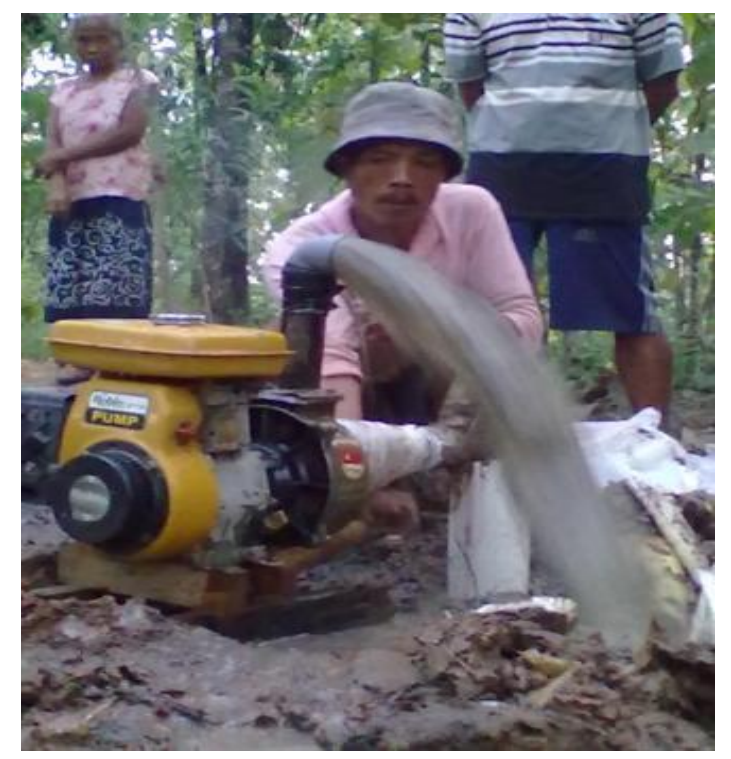

Gambar 1.4 Air Keluar dari Sumur Bor

\section{KESIMPULAN}

Berdasarkan hasil pelaksanaan PkM, dapat diambil kesimpulan bahwa masyarakat desa Kwadungan lebih bersemangat dan mampu untuk memperbaiki kualitas hidupnya jika ada pembinaan atau pengarahan secara intensif. Hal ini dapat dilihat dari Program Pengabdian yang telah dilaksanakan disambut dengan baik bahkan warga mau bergotong royong untuk menutup kekurangan dana pembelian pompa air. Dibutuhkan waktu yang cukup lama untuk memahamkan seluruh masyarakat dan terjadinya sebuah kesepakatan. Pada akhirnya, proses pemasangan Sumur Bor dapat dilaksanakan dengan baik, dan tidak terlepas dari proses pengawasan dan pengarahan dari pihak pemberi bantuan.

Dengan adanya Pompa Air Harapan ini masyarakat desa Kwadungan Lor lebih mudah untuk memenuhi kebutuhan air dan mengembangkan hasil bercock tanam ketika msuim kemarau agar tidak terjadi gagal panen, dan masih bisa mendapatkan keuntungan dari hasil bercocok tanam. Segala bentuk aturan dan kesepakatan diputuskan secara musywarah oleh warga dan para petinggi desa, sehingga warga yang membuat sendiri aturanya serta melaksanakannya dengan baik.

\section{SARAN}

Lahan yang sangat luas adalah potensi utama yang dimiliki Desa Kwadungan Lor. Dari potensi tersebut dapat dikembangkan banyak sekali usaha yang dapat menaikan pendapatan masyarakat desa, seperti budidaya ikan lele, sentra kuliner tradisional seperti keripik ketela atau pisang, juga berbagai makanna lainnya. Terlebih jika dibuat 
1-2 lagi pompai air umum di beberpa titik, maka ketersedian air akan lebih merata dan masyarakat tidak hanya mudah tapi juga lebih cepat mendapatkan air untuk mengembangkan potensi lahan yang kosong.

\section{DAFTAR PUSTAKA}

Putri A. Melati, dkk. "Sistem Aliran dan Potensi Air Tanah di Sebagian Desa Sembangun Ditinjau dari Aspek Kualitas dan Kuantitas" (2018) 32:2 Majalah Geografi Indonesia 155.

Musyarofah, dkk. "Prefensi Petani dalam Penjualan Gabah Pasca Panen di Desa Sumur Mati, Kecamatan Sumber Asih, Kabupaten Probolinggo" (2017) 11:1 Jurnal Pendidikan Ekonomi 81.

Sunarsih Ernawati S, "Air Bersih untuk Masyarakat Miskin dengan Sumur Bor" (2012) 3:2 Journal of Rural and Development 113.

Wibowo Agus T., M. Zen Kadir, Iskandar Zulkarnanen, "Peranan Sumur Bordalam Mengefektifkan Penyediaan Air Bersih Masyarakat Kampung Sukamanjur Kelurahan Bumi Kedamaian" (2015) 1 Artikel Ilmiah Teknik Pertanian Lampung 19. 